Prepared in cooperation with the U.S. Environmental Protection Agency

\title{
Simulation of Groundwater Flow in a Volatile Organic Compound-Contaminated Area near Bethpage, Nassau County, New York-A Discussion of Modeling Considerations
}

Open-File Report 2011-1128 
This page has been left blank intentionally. 


\section{Simulation of Groundwater Flow in a Volatile Organic Compound-Contaminated Area near Bethpage, Nassau County, New York-A Discussion of Modeling Considerations}

By Paul E. Misut

Prepared in cooperation with the U.S. Environmental Protection Agency

Open-File Report 2011-1128 


\section{U.S. Department of the Interior \\ KEN SALAZAR, Secretary \\ U.S. Geological Survey \\ Marcia K. McNutt, Director}

\section{U.S. Geological Survey, Reston, Virginia: 2011}

For more information on the USGS - the Federal source for science about the Earth, its natural and living resources, natural hazards, and the environment, visit http://www.usgs.gov or call 1-888-ASK-USGS.

For an overview of USGS information products, including maps, imagery, and publications, visit http://www.usgs.gov/pubprod

To order this and other USGS information products, visit http://store.usgs.gov

Any use of trade, product, or firm names is for descriptive purposes only and does not imply endorsement by the U.S. Government.

Although this report is in the public domain, permission must be secured from the individual copyright owners to reproduce any copyrighted materials contained within this report.

Suggested citation:

Misut, P.E., 2011, Simulation of groundwater flow in a volatile organic compound-contaminated area near Bethpage, Nassau County, New York—A discussion of modeling considerations: U.S. Geological Survey Open-File Report 2011-1128, 19 p., at http://pubs.usgs.gov/of/2011/1128/. 


\title{
United States Department of the Interior
}

\author{
U. S. GEOLOGICAL SURVEY \\ NEW YORK WATER SCIENCE CENTER \\ 2045 Rt. 112 \\ Coram, NY 11727 \\ (631) 736-0783
}

June 3, 2011

Mr. Robert Alvey, P.G.

Technical Support Team

U.S. Environmental Protection Agency, Region II

Emergency and Remedial Response Division

Program Support Branch

290 Broadway, 18th Floor

New York, NY 10007-1866

Subject: Simulation of Groundwater Flow in a VOC-Contaminated Area near Bethpage, Nassau County, New York-A Discussion of Modeling Considerations

Dear Mr. Alvey:

The U.S. Geological Survey (USGS) was requested by U.S. Environmental Protection Agency (USEPA) to conduct a limited review and assessment of groundwater model(s) developed by consultants for Northrup Grumman Corporation in connection with the Grumman and Navy sites in Bethpage, New York, and contaminated groundwater flow potentially affecting public-supply wells. The focus of this review and assessment was necessarily limited and could not be conducted by fully utilizing the 2004 USGS Guidance document (Reilly, T.E., and Harbaugh, A.W., 2004, Guidelines for evaluating ground-water flow models: U.S. Geological Survey Scientific Investigations Report 2004-5038; http://pubs.usgs.gov/ sir/2004/5038/), because apparently a comprehensive calibration document has not been produced. Nevertheless, reviewers and users of this study have a need to evaluate the accuracy and reasonableness of the current groundwater model. Thus, the review is intended to identify ways of improving these aspects of the model, and to explain the limitations of the modeling analysis and models in general. This report, USGS Open-File Report 2011-1128, represents USGS publication of the subject review submitted to USEPA on April 4, 2011. If you have any questions or comments about the information I have provided, please do not hesitate to telephone me at the above number or email me at pemisut@usgs.gov.

Sincerely,

Paul E. Misut

Hydrologist 
This page has been left blank intentionally. 


\section{Contents}

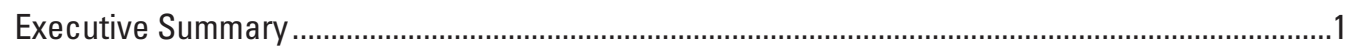

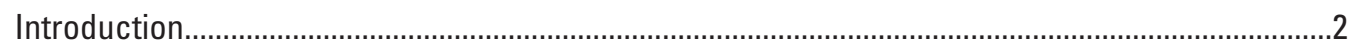

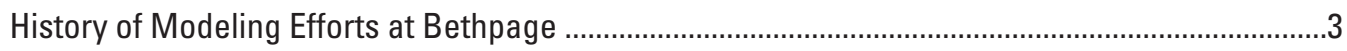

Considerations in Groundwater-Flow Simulation .....................................................................

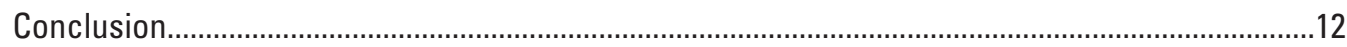

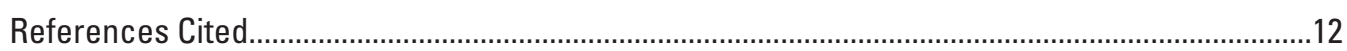

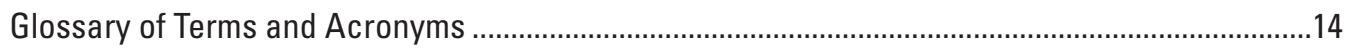

\section{Figures}

1. Map showing location of Public Water Districts surrounding Naval Weapons Industrial Reserve Plant, Bethpage, Nassau County, New York........................................2

2. Graph showing total volatile organic compounds (TVOC) at onsite containment system (ONCT) pumping wells, 1998 to 2010 ...............................................................

B2-1. Diagram showing conceptual overview of representing complex hydrogeological

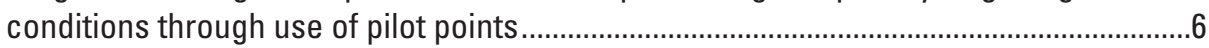

3. Graph showing monthly rate of pumpage at Bethpage Well 6-2......................................7

4. Graphs showing groundwater level at Well N1259 in Bethpage and precipitation at National Weather Service station at Mineola, Nassau County, New York, 1950-2000.....9

5. Cross section showing groundwater ages along Nassau-Suffolk County border prior to development . .10

6. Map showing predicted maximum declines in the water table as a result of sewer

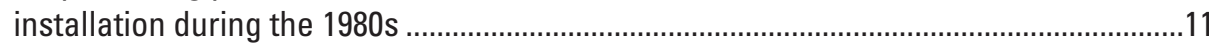

\section{Table}

1. History of Bethpage groundwater model applications and updates ................................18 


\section{Conversion Factors and Datums}

\begin{tabular}{lcl}
\hline & Multiply & \multicolumn{1}{c}{ To obtain } \\
\hline inch (in.) & Length & \\
foot (ft) & 2.54 & centimeter $(\mathrm{cm})$ \\
mile (mi) & 0.3048 & meter $(\mathrm{m})$ \\
\hline & 1.6093 & kilometer $(\mathrm{km})$ \\
\hline gallon (gal) & Volume & \\
\hline & 3.785 & liter $(\mathrm{L})$ \\
\hline foot per year (ft/yr) & Flow Rate & \\
\hline
\end{tabular}

Vertical coordinate information is referenced to the National Geodetic Vertical Datum of 1929 (NGVD 29).

Horizontal coordinate information is referenced to the North American Datum of 1983 (NAD 83).

Concentrations of chemical constituents in water are given either in parts per billion (ppb) or micrograms per liter ( $\mu \mathrm{g} / \mathrm{L})$. 


\title{
Simulation of Groundwater Flow in a Volatile Organic Compound-Contaminated Area near Bethpage, Nassau County, New York-A Discussion of Modeling Considerations
}

\author{
By Paul E. Misut
}

\section{Executive Summary}

The 2010 Bethpage groundwater-flow model (ARCADIS, 2010) was based on a steady state ${ }^{1}$ assumption. Although it is widely acknowledged that significant water-level changes have occurred in the past, the reviewed model does not represent changing water levels. The steady state approach limits the effectiveness of the following:

1. identification of sources of contamination,

2. analysis of model accuracy,

3. model calibration, and

4. simulations of future scenarios.

Future plume movement was simulated in an incomplete manner through an unchanging groundwater-flow field. Available time-series information on temporal variation of factors affecting groundwater-flow dynamics includes:

1. public-supply pumping,

2. groundwater discharges from systems remediating volatile organic compound (VOC) plumes,

3. recharge and precipitation rates, and

4. water levels and streamflows.

Transient phenomena that might be useful in future hypothetical simulations include pumping variations, redirection of containment-system waters for industrial use, and climate-change scenarios. Public-domain computer programs, U.S. Geological Survey guidance reports on transient-state calibration and uncertainty methods (Doherty and Hunt, 2010), and additional local and regional datasets are available to provide additional confidence in model evaluations and allow better evaluation of their limitations.

${ }^{1}$ Glossary terms and acronyms in bold are defined in the glossary and list of acronyms on page 14. 


\section{Introduction}

The U.S. Geological Survey (USGS) was requested by the U.S. Environmental Protection Agency (USEPA) to provide an opinion as to whether a consultant's current groundwater model of plumes emanating from the Northrup Grumman and Navy sites at Bethpage, New York (fig. 1) is sound and appropriate. The product of this review is the following technical memo, intended to assist modelers in improving the accuracy and reliability of their models, and to explain the limitations of such models. This review provides (1) a brief history of modeling efforts at Bethpage, and (2) describes the use of techniques, existing datasets, and data-collection activities for the purpose of gaining additional confidence in model evaluations and better judging the uncertainty level and limitations inherent in model evaluations.

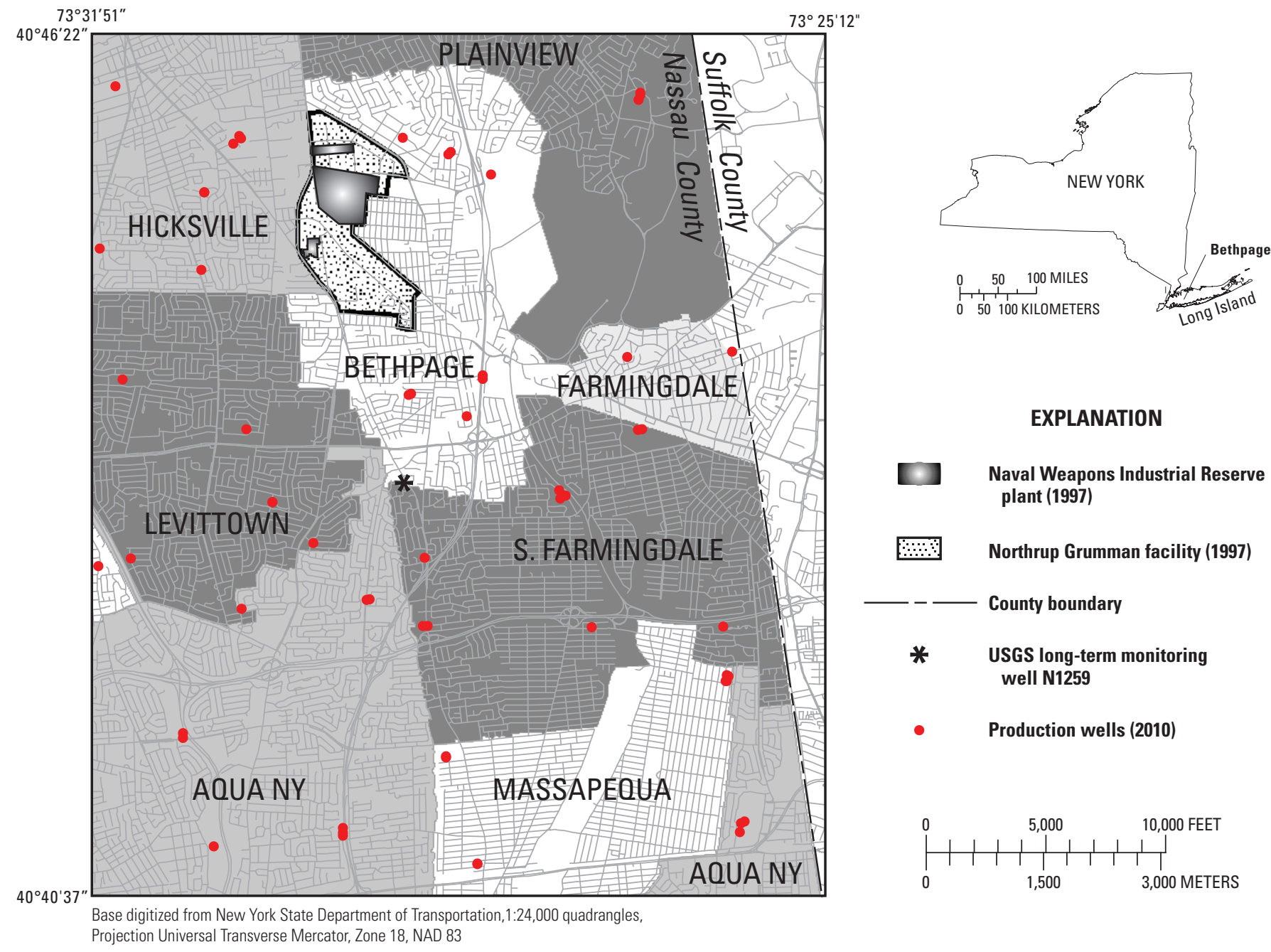

Figure 1. Location of Public Water Districts surrounding Naval Weapons Industrial Reserve Plant, Bethpage, Nassau County, New York. 


\section{History of Modeling Efforts at Bethpage}

USGS modeling of the groundwater-flow system of Nassau County began prior to the advent of computers and modeling of the Bethpage area culminated with a 1992 particle tracking analysis (Smolensky and Feldman, 1995) conducted in cooperation with the Nassau County Department of Health (NCDH). Water particles were depicted moving (1) towards deep industrial pumping wells located on the Bethpage Northrup Grumman site, and (2) away from surface recharge basins where particles representing water captured by industrial wells were reintroduced. This pumping-recharge cycle resulted in rearrangement and partial containment of a plume of volatile organic compounds (VOCs) generally migrating in a southward direction toward the Levittown area at a rate of about 200 feet per year (Smolensky and Feldman, 1995). The analysis also indicated that some particles applied at the water table upgradient of onsite recharge basins were drawn into the deep zones of onsite well influence but not captured, and ultimately discharged at the southern model boundary in the Levittown area in the bottom 10 percent of the lowest model layer.

From 1995 to the present, consultants have developed a series of models that are generally consistent with the earlier USGS work but depict greater containment of onsite VOCs. In 1995, a flow model was used to help design a complete onsite hydraulic containment system (ONCT) at the Northrup Grumman facility. In 1998 analysis of field data concluded that ONCT was operating effectively (Smith, 2011 $\mathrm{a}^{2}$ ); however, estimation was needed of when solutes already downgradient of ONCT at the time of its initiation would reach production wells. In response, additional flow modeling was used in 2002 to identify locations for monitoring wells to provide a 5-year early warning to downgradient public-water suppliers potentially impacted (Smith, $2011 \mathrm{a}^{2}$ ). In 2010, a solute transport model was used to evaluate potential remediation actions at offsite "hot spots" where elevated levels of contamination were observed southeast of ONCT (Smith, 2011 $\mathrm{a}^{2}$ ). Although a thorough calibration document has not yet been produced for the 2010 model and its reliability cannot be thoroughly assessed, this 2010 model has become an indispensible tool for planning future remedial action (ARCADIS, 2010) due to the complexity inherent in system response to proposed stresses.

The history of model application at the Bethpage site is tempered by unanticipated observations and revisions including the following:

1. A second groundwater remedial investigation of operable unit 3 (OU3), begun in 2004, delineated a separate plume that commingled with the original operable unit 2 (OU2) plume and the capture zone of ONCT Well 19 (Smith, $2011 b^{3}$ ). The increasing concentration of contaminated water captured at ONCT Well 19 (fig. 2) was contrary to the predicted (ARCADIS, 2003) decreasing trend for that site and may be attributed to the OU3 source.

2. Modeled trends in ONCT capture of contaminants originating from the USEPA Hooker/Ruco Superfund site (Occidental Chemical Corporation, 1996) did not match observations (Smith, 2011 b ${ }^{3}$ ); stated lack of formal model documentation (Occidental Chemical Corporation, 1996) may have contributed to this discrepancy.

3. The outpost monitoring well associated with an Aqua, New York wellfield, sited through modeling, failed to provide early warning of VOC arrival in 2009; that is, VOCs were detected in the production well pumpage before they were detected at the associated upgradient outpost monitoring well. This failure has been attributed to inaccurate delineation of the leading edge of the plume (Smith, 2011 $\mathrm{c}^{4}$ ).

4. VOC detection at an outpost well associated with the South Farmingdale production Wellfield \#1 occurred sooner than predicted (Smith, 2011 $\mathrm{c}^{4}$ ). A water sample collected immediately after outpost well installation contained VOCs (R. Humann, H2M, oral commun., 2011). Uncertainty of estimated arrival time may limit the usefulness of outpost wells to provide sufficient notification to plan and construct treatment for the wellfield.

5. The models did not accurately reproduce the pumpage rate-related pattern of VOC concentration observed at Bethpage Water District Well 6-2 (R. Humann, H2M, oral commun., 2011; Smith, 2011d ${ }^{5}$ )

\footnotetext{
${ }^{2}$ Smith, K., 2011a, "History of Bethpage Groundwater Model Applications and Updates”, Northrup Grumman, written commun., 01/31/2011, see appendix A.

${ }^{3}$ Smith, K., 2011b, Presentation to Navy Remedy Validation and Optimization Team, Northrup Grumman, written commun., 02/8/2011.

${ }^{4}$ Smith, K., 2011c, Subject: December 14, 2010 Memo "Preliminary Review of Model Used for Comprehensive Feasibility Study", Northrup Grumman, written commun., 02/10/2011.

${ }^{5}$ Smith, K., 2011d, "Responses to 9 Questions Received December 10, 2010 from the USGS on the Northrup Grumman Regional Groundwater Flow and Transport Model”, Northrup Grumman, written commun., 1/28/2011.
} 
6. Observed total VOC concentrations above 100 parts per billion (ppb) near the bottom of vertical profile boring VP-47 (below a depth of 710 feet) are not represented in the model; this is attributed to the age and relative isolation of the VOC observations (Smith, 2011d $\mathrm{d}^{5}$ ).

7. A model layering scheme was locally updated with the addition of a confining layer overlying the screen zone of Bethpage Water District Well 5-1 (Smith, 2011d $)$.

8. Models required revisions to steady state pumping and recharge rates (Smith, 2011 $\left.\mathrm{a}^{2}\right)$ yet do not address stressed conditions that affect the hydraulics of the region. Steady state configurations imply time-invariant pumping and recharge rates; however, model changes have been necessary.

Uncertainties inherent in model simulations, such as those conducted for the Bethpage site, have been widely documented (Konikow, 2010) and will likely lead to further model updates as new field data and modeling methods become available. It may be important to consider the effects of model revision on previously simulated results. Some model uncertainties are expected to continue and may be addressed through presentation of alternate model configurations and parameter-sensitivity analysis.

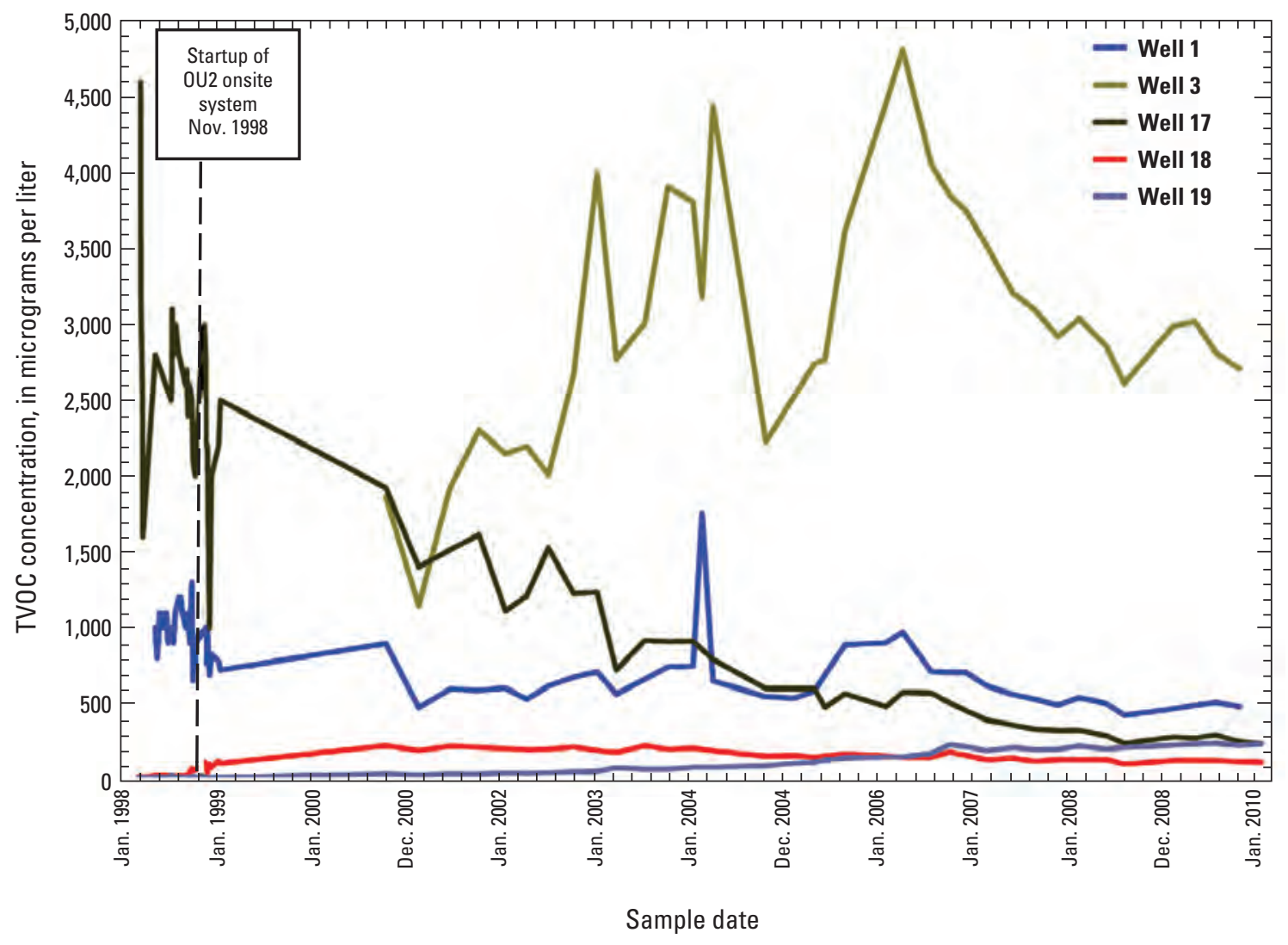

Figure 2. Total volatile organic compounds (TVOC) at onsite containment system (ONCT) pumping wells, 1998 to 2010. (From Smith, 2011b3) 


\section{Considerations in Groundwater-Flow Simulation}

The following section describes the use of techniques, existing datasets, and data-collection activities for the purpose of gaining additional confidence in model evaluations and (or) better judging the uncertainty level and limitations inherent in model evaluations. Topics include (1) the complex heterogeneous nature of the Magothy aquifer, (2) parameter estimation methods including pilot points, (3) types of dynamic response present in the Bethpage groundwater-flow system, (4) steady- and transient-state simulation methods, and (4) migration of contaminants across zones of contrasting permeability.

Aquifer Complexity - The Magothy aquifer and the upper zone of the Raritan formation are heterogeneous mixtures of highand low-permeability materials through which groundwater flows preferentially within the permeable materials. Thus, the failure of an outpost monitoring well installed to provide early warning of VOC arrival at the Aqua New York production well (Smith, $2011 \mathrm{c}^{4}$ ) may have resulted from movement of solutes into the pumping well through a highly permeable zone that was not tapped by the outpost monitoring well. The fact that many of the low-permeability zones observed in boreholes do not extend from one location to another led Kent Smith (Northrup Grumman Corporation) to the conclusion that bulk anisotropy should be specified in models:

"Recognizing the variability that has been observed in individual boreholes only tends to emphasize the lack of defined variability between boreholes. As employed in the model, use of assigned anisotropy values to represent lithologic variability (which accounts in a bulk fashion for the vertical variability in aquifer material) is a tested and reliable modeling technique" (Smith, 2011 c $)$

Models were divided into minimal anisotropy zones. Five zones were included in the 1998 model (ARCADIS, 2003) and later studies added zones, among which were a localized confining layer at Bethpage plant 5 (Smith, $2011 \mathrm{~d}^{5}$ ), which lies in an area that had apparently been mapped by the modeler in greater detail than other potential zone candidates. The approach, however, generally remained one of establishing a minimal number of zones, then manually adjusting associated parameters through trial and error to match a simplified steady state approximation of a subset of water levels. Thus, the result is a simplified representation of Magothy aquifer heterogeneity that differs fundamentally from that suggested by gamma logs, water-level hydrographs, outpost monitoring well failure, and other lines of evidence.

The large amount of computational work inherent in solving the flow and transport equations requires that modelers strive for parsimony - that is, the maximum simplicity attainable without ignoring or excluding critical factors. For example, minimally-zoned models may have greater parsimony than models featuring complex zonations in simple homogeneous settings. Conversely, in complex settings, a simple minimally-zoned model is not parsimonious. In order to judge model parsimony, it is useful to consider those factors critically affecting simulation results, and discuss how to improve their representation. 
Parameter estimation-In models striving to represent heterogeneous mixtures of high- and low-permeability materials, an alternative to pre-assigning a minimal zonal structure to a model would be to implement a more flexible, highly parameterized approach such as provided by the public domain code PEST (acronym for Parameter ESTimation, Doherty and Hunt, 2010). PEST reformulates the groundwater calibration problem such that large numbers of parameter zones become tractable and yield a parsimonious model. Among the benefits of PEST is the ability to provide sophisticated estimates of parameter and predictive uncertainty. The following excerpt from USGS guidelines (Doherty and Hunt, 2010) describes and illustrates PEST pilot points, a method in which traditional parameter zones are replaced with a matrix of points:

"The general goal of pilot points is to provide a middle ground between cell-by-cell variability and reduction to a few homogeneous zones for characterizing natural-world heterogeneity in groundwater models. Figure B2-1 depicts a schematic representation of the pilot-point implementation. In figure B2-1A, a heterogeneous field is depicted overlain by a model grid. This illustrates that, even at the model-cell scale, the representation of heterogeneity requires simplification. In figure B2-1B, a network of pilot points is shown in which the size of the circle is proportional to the parameter value and the color represents the value on the same color scale as in figure B2-1A. The general pattern of variability in the true field is visible in this image, but the resolution is much coarser than reality. Figure B2-1C shows the pilot-point values interpolated onto a very fine grid and illustrates that much of the true heterogeneity can be reconstructed from a subset of sampled values provided that appropriate interpolation is performed. Figure B2-1D shows the interpolated version of the pilot-point values in figure B2-1B on the model-cell grid scale, which represents the version of reality that the model would actually see. In reality, rather than directly sampling the true field as in this illustration, the pilot points are surrogates for the real parameter field estimated from observations in the calibration dataset and are therefore likely to include some error not depicted on this figure. However, the schematic representation depicts the best possible representation of the real field given the displayed density of pilot points."
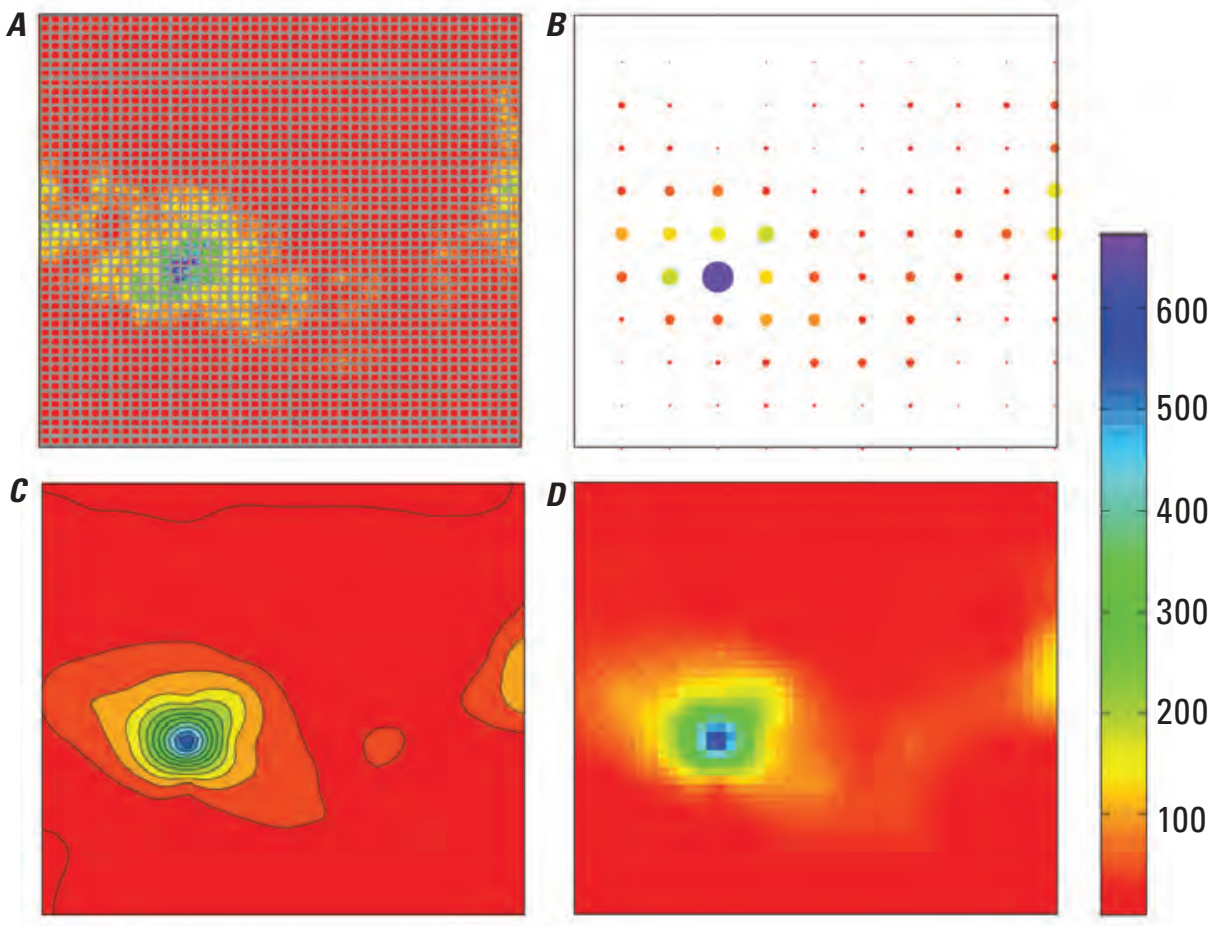

Figure B2-1. Conceptual overview of representing complex hydrogeological conditions through use of pilot points. Panel $A$, shows the inherent property value overlain by the model grid in gray. Panel $B$ is a representation of the true property values by a grid of pilot points in which symbol size indicates value. Panel $C$ shows an interpolated representation of panel $B$ on an arbitrarily fine grid scale. Panel $D$ shows the value from the pilot points interpolated to the computational-grid scale. Interpolation in all cases was done by using ordinary kriging. The same color scale applies to all four panels. (From Doherty and Hunt, 2010) 
Seasonal pumping stresses-Pumping by Nassau County water suppliers varies by season and other factors such as shutdown/ rebalancing due to water quality degradation. For example, summer pumpage at Bethpage production Well 6-2 (figures 1, 3) may be more than 10 times greater than winter pumpage, as illustrated in the following 1982-2009 hydrograph showing summer. For nine months starting in August 2007, Well 6-2 was taken offline due to elevated summer VOC concentrations (greater than $800 \mathrm{ppb}$ total VOC, R. Humann, H2M, oral commun., 2011). Temporal variations in pumping rates and other stresses enhance plume spreading and may explain why solute concentrations increase at production wells that are pumped heavily in summer.

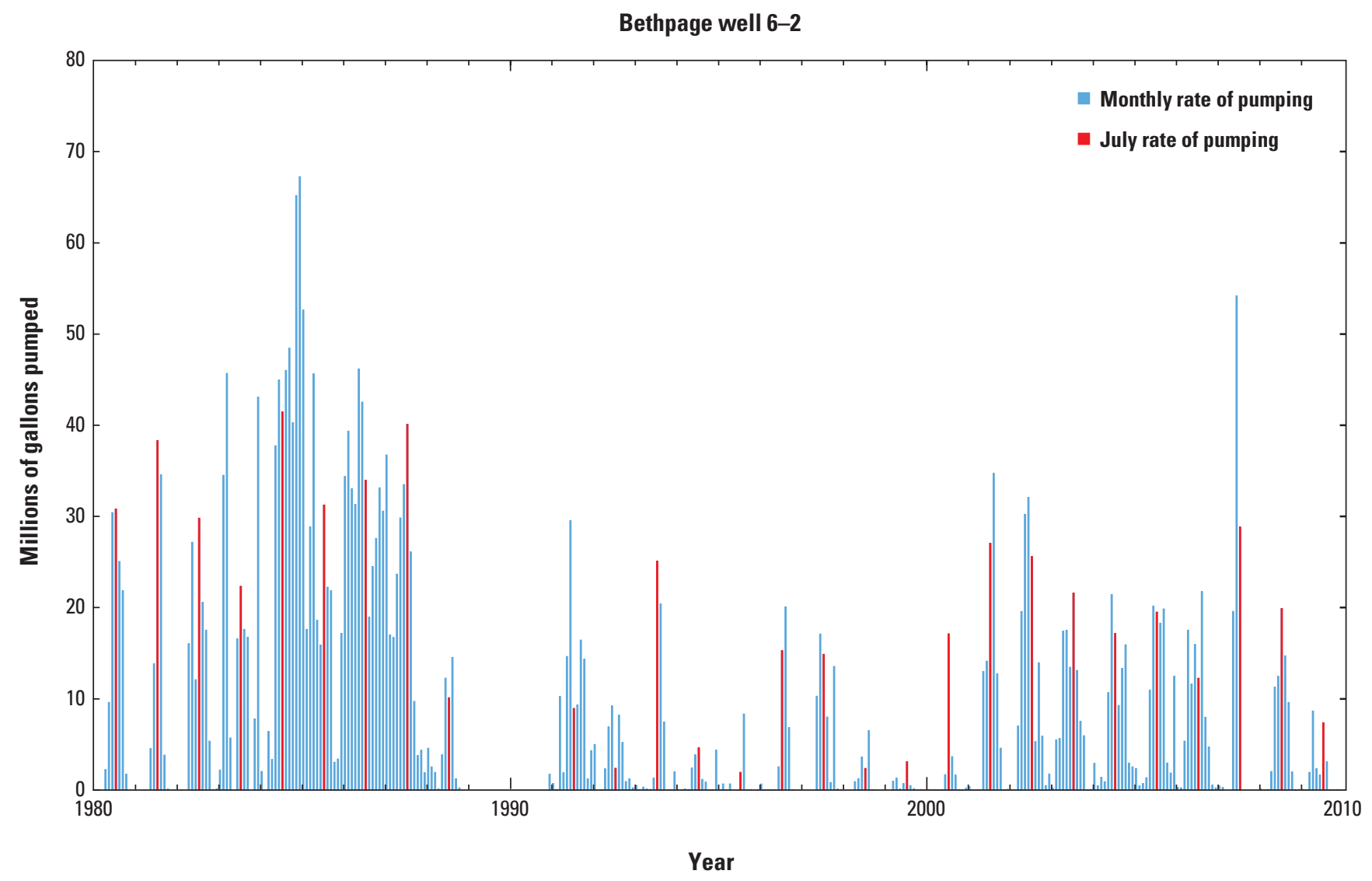

Figure 3. Monthly rate of pumpage at Bethpage Well 6-2. (Data may be unavailable for 1989-90) (J. Monti, Jr. and J. Hock, U.S. Geological Survey, written commun., 2011) 
Steady state and transient representation - The consultant (Smith, 2011d $\mathrm{d}^{5}$ ) states:

'With the exception of local variations (i.e., proximal to production wells), temporal or cyclical changes in water levels (both historical and for long-term predictions) have not, nor will they significantly impact long-term average groundwater-flow directions and rates. This concept is discussed in detail in "Effect of Seasonal and Long-Term Changes in Stress on Sources of Water to Wells, WSP-2445."

The referenced USGS Water-Supply Paper 2445 (Reilly and Pollock, 1995) presents an analysis of simplified, hypothetical, steady state and transient-state models and concludes that the particle pathlines generated by transient-state simulations are smoothed and become similar to those generated under averaged steady state conditions when the simulation time includes several stress cycles. However, Reilly and others further conclude the following two points:

1. The differences between a steady state and transient-state estimate of the capture zone "could be significant" (Reilly and Pollock, 1996) near the boundaries of the capture zone or at small distances from the sources of transient effects.

2. The area contributing recharge to a well (for the given system geometry and boundary conditions) is independent of porosity in a steady state simulation but not in a transient-state simulation (Reilly and Pollock, 1996).

Comparison of particle pathlines within steady state and transient-state flow systems by Festger and Walter (2002) demonstrated further significant differences between the two approaches.

Aquifer tests - Aquifer tests are controlled, transient-state experiments in which pumpage is intentionally varied while waterlevel dynamics in nearby monitoring wells are observed through continuous water-level recorders, and aquifer hydraulic properties are estimated through model parameter inversion. The testing period is typically a few days to minimize the effect of other factors that affect water levels over longer time scales. The inversion process uses least squares minimization to identify parameter values that provide the closest match between simulated and observed water levels. Production well test stress may be generally anticipated to radiate laterally at least 3,000 ft in the semiconfined Magothy aquifer (Misut and Busciolano, 2009), such that multiple monitoring points are instrumented for most wellfields. The cessation of supply-well pumping during an aquifer test commonly requires that demand in the water-supply system be accommodated through additional pumpage at a different wellfield. This can potentially lead to well interference; therefore, careful test planning includes collection of pumpage data at all affected wellfields.

Estimates of hydraulic properties from site-specific aquifer tests can be expected to be more accurate than values estimated through minimally-zoned regional model calibration; through use of PEST (Doherty and Hunt, 2010), model calibration may be conducted such that aquifer test estimates locally outweigh other tendencies for parameter adjustment. As yet, no aquifer tests are known to have been conducted at any wellfields in the area of interest; regional models could benefit from such data.

Correlation of water levels and precipitation - Nearly all water entering the groundwater-flow system of the Bethpage area (and Nassau County) consists of recharge from precipitation. Groundwater levels reflect the seasonal and long-term variations in precipitation rate, as illustrated by the correlation between water levels and precipitation in the hydrographs for 1950-2000, (fig. 4). Water levels at Well N1259 are not in a steady state condition; rather, they fluctuate seasonally and show trends over longer periods. Model representation of these transient conditions can serve many purposes and may improve estimates of the following:

1. Hydraulic property variation and aquifer geometry: Among the hydraulic properties whose values could be better estimated through transient-state than through steady state simulation are porosity, horizontal and vertical hydraulic conductivity, and storativity.

2. Model boundary flows: The spatial and temporal distribution of recharge may be obtained in a manner similar to estimation of the spatial distribution of hydraulic properties.

Examples of distinct spatial recharge zones, some of whose values may vary in time, include stormwater recharge-basin zones, zones of treated water discharge, residential zones, and impervious zones. The public domain code PEST includes powerful transient-state calibration and uncertainty analysis techniques for complex models, and USGS guidelines are available (Doherty and Hunt, 2010). 

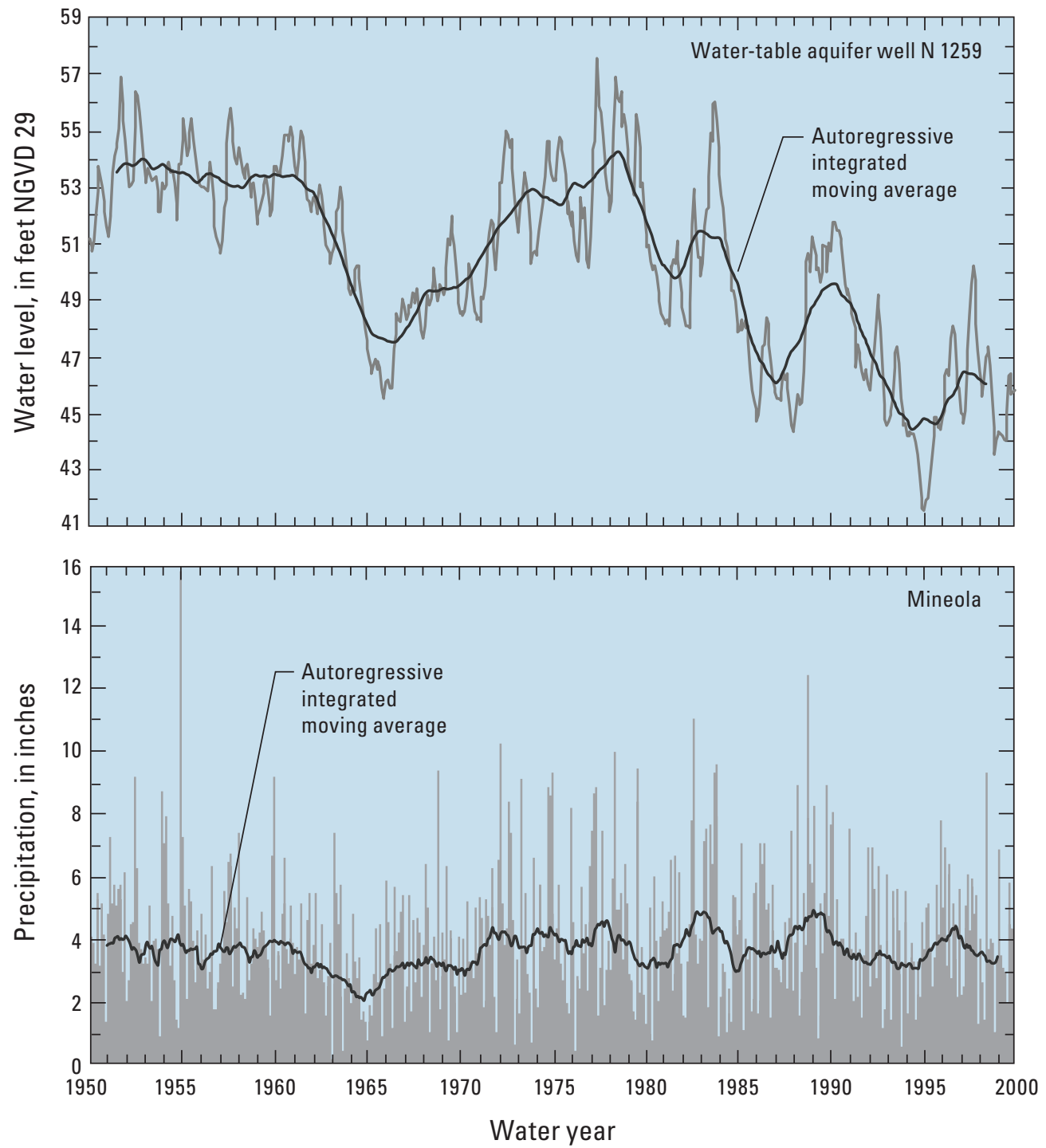

Figure 4. Groundwater level at Well N1259 in Bethpage and precipitation at National Weather Service station at Mineola, Nassau County, New York, 1950-2000. (Location of well shown in figure 1.) (Modified from Busciolano, 2005) 
Migration of contaminants into poorly-permeable zones-Solutes migrate into poorly-permeable zones through diffusion and slow advection, and are stored in dissolved and sorbed phases. When dissolved-phase concentrations in adjacent, more permeable zones decrease, the diffusion gradient reverses and allows the slow release of stored material from the poorlypermeable zones (Newell, 2011). Adjacent contrasting permeability zones are present within the upper glacial and Magothy aquifers, and within the Raritan confining unit. Analytical models are available to simulate the full range of diffusion and slow advection mechanisms, but numerical models are not currently practical. However, a “dual domain porosity” process has been tractable in numerical models and assumes diffusion-only mass transfer without slow advection. The 2010 Bethpage model was updated to simulate the dual-domain porosity process. The resulting summary report concluded that implementation of the dual domain porosity would not affect the conclusions reached in the OU3 feasibility study (FS) (ARCADIS, 2010). In further discussions, it was stated that no significant change in simulated results was evident during sensitivity analysis of dual domain porosity parameters (Smith, 2011 $\mathrm{c}^{4}$ ). However, it was also stated that "lack of sensitivity does not necessarily equate to non-improvement in predictions, " and not accounting for dual domain processes would not allow representation of the physical processes that are occurring within the groundwater system (Smith, 2011 $\mathrm{c}^{4}$ ). Although the dual domain process has become tractable in numerical models, in practice, it has been found that dual domain porosity parameters are scale dependent, lack physical significance, and are used primarily as a data-fitting, as opposed to a predictive tool (Flach and others, 2004). Dual-domain porosity parameters used in the Bethpage model are an incomplete representation of the processes by which contaminants migrate between contrasting permeable zones, because slow advective movement is not represented.

Prior to any attempt to represent matrix diffusion, a more complete calibration and sensitivity analysis of porosity-of the traditional single-domain "effective porosity" type in a fully transient state analysis - should be considered. This parameter controls the rate of advective movement and may be adjusted and zoned to improve match to field observations of the rate of plume movement, thus (1) building confidence in the ability of the model to predict plume arrival times at water-supply wells, (2) leading to discoveries about the uncertainties inherent in plume arrival time prediction, and (3) providing guidance for future data collection activities.

Model bottom-The Raritan confining unit (fig. 5) includes an upper zone that has greater heterogeneity and permeability than the full thickness of the formation. Water enters this upper zone and constituents such as VOCs can migrate into this upper zone. The lower portion of the Raritan confining unit can reasonably be used as a bottom boundary even though there is obviously some pathway within the formation that results in recharge of the underlying Lloyd aquifer.

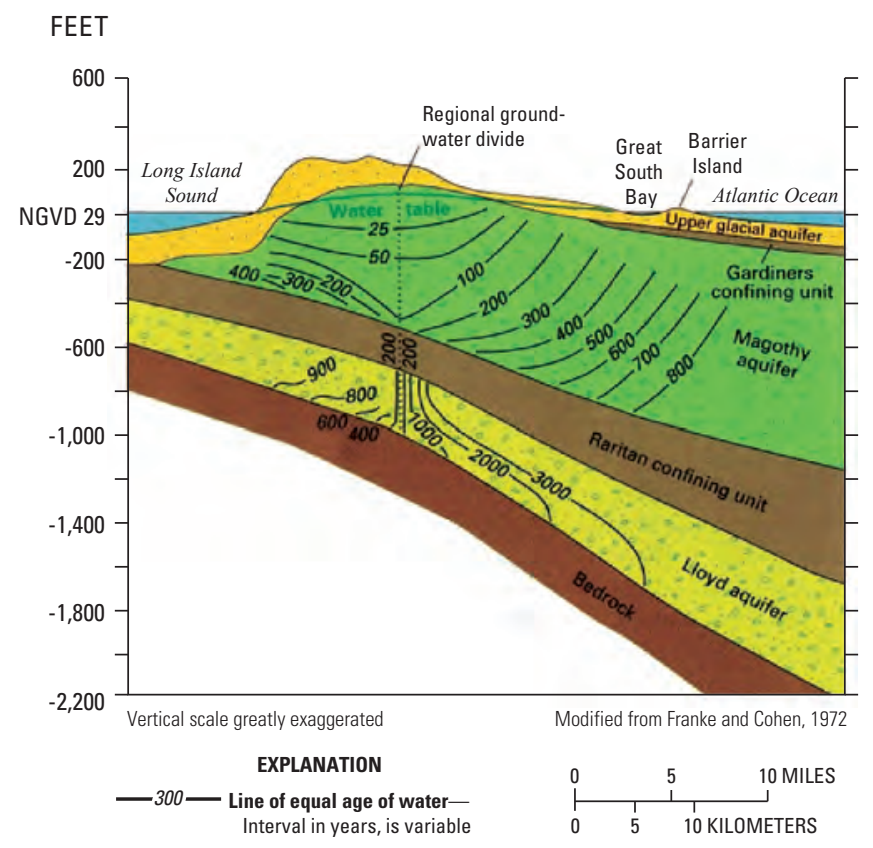

Figure 5. Cross section showing groundwater ages along Nassau-Suffolk County border prior to development. (Location of border shown in figure 1. Modified from Olcott, 1995) 
Sewer installation-Model parameter estimates — including workable estimates of VOC source loading terms — may be improved through transient-state calibration. Contemporary calibration methods, including PEST (Doherty and Hunt, 2010), facilitate the transient-state approach. The contaminant plumes appear to have migrated through a dynamic transient-state flow field. Previous sections treated dynamic changes resulting from pumping well stresses over several time scales, and variation in precipitation. Another cause of change, and opportunity for improved model calibration, is historical analysis of the installation of sewer systems in Nassau County during the 1980s, which resulted in complex changes in head surfaces during a period of significant VOC loading at Bethpage. Maximum water table declines that were predicted by the USGS Long Island regional model to result from 1980s sewer installation are depicted in figure 6 . The size and shape of current plume have been influenced by sewer installation.

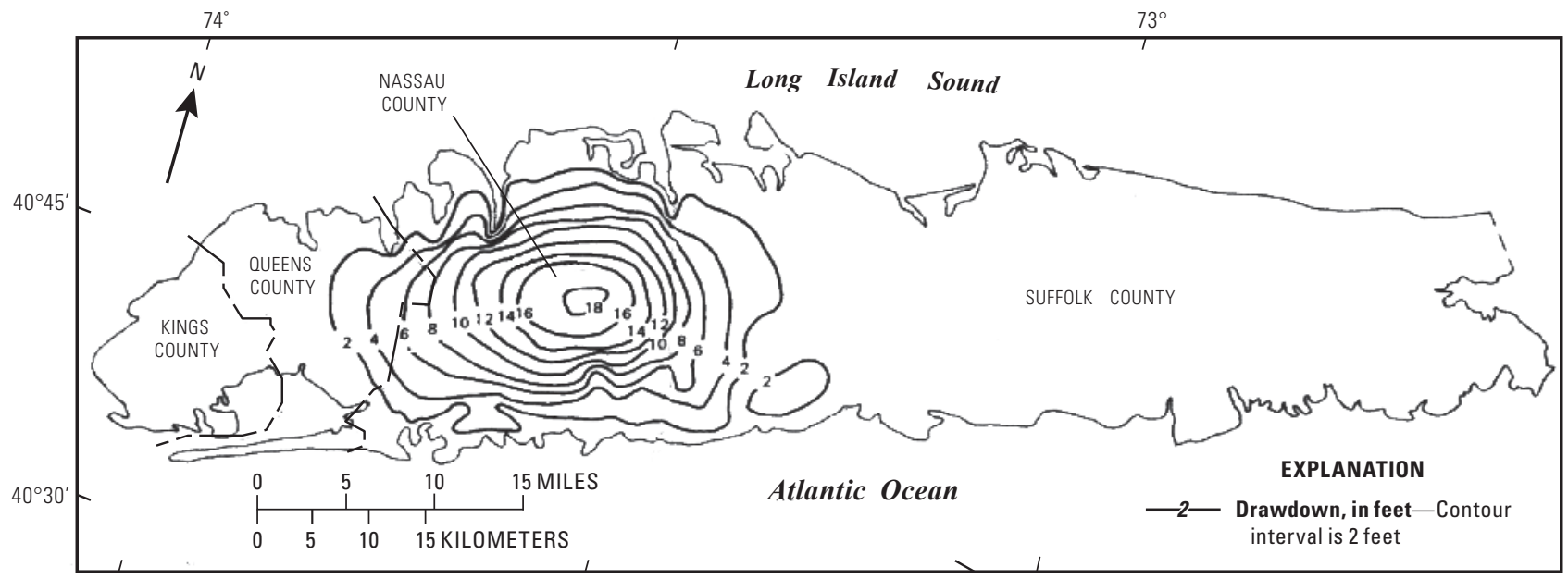

Figure 6. Predicted maximum declines in the water table as a result of sewer installation during the 1980s. (From Reilly and others, 1983)

Interpolation during calibration-Model calibration entails comparison of simulated to observed values and typically entails interpolation of discretized model results to the precise location of field observations. The cell center method has been used and the following is stated by the consultant:

"Residuals are calculated by comparing the model-predicted head (at the cell center) to the target value (field measured value-not necessarily at the cell center). Given the larger size of the cells away from the areas of greatest interest and the likelihood that the largest head changes occur within some of the largest model cells (due to a relatively uniform gradient across the entire model domain) it would be expected that a target not located coincident with the center of the model cell (where the model head is calculated) could exhibit an increase in calibrated residual simply as a function of cell size" (Smith, 2011d $\mathrm{d}^{5}$

Among other capabilities mentioned previously, PEST (Doherty and Hunt, 2010) methods typically interpolate simulated values to the precise location inside a cell, resulting in more accurate calculation of residual values than the cell center method. 


\section{Conclusion}

An understanding of how plumes evolve over time may be useful in assessing questions as to whether (1) all sources of contamination been identified, (2) a model plausibly generates the current plume configuration, and (3) rates of plume migration toward production wells are constant. Review of the model and discussion with the Bethpage model consultants indicates an assumption was made that significant water-level changes occurred only in the past, and that the flow system is now stable and may be modeled as a steady state system starting from a hand-drawn initial condition of plume state, subject to revisions as necessary. The consultant approach ignores information on temporal variation of several factors, including

- public-supply pumping,

- groundwater discharges from systems remediating VOC plumes,

- recharge and precipitation rates, and

- water levels and streamflows.

Such an approach also ignores the potential for future variation in the above factors. Transient phenomena that may lend themselves to prediction in future hypothetical simulations include pumping cycles, redirection of containment-system waters for industrial use, and climate-change scenarios. Public-domain computer programs, USGS guidance reports on transient-state calibration and uncertainty methods, and additional local and regional datasets are available to gain additional confidence in model evaluations and better judge their limitations.

\section{References Cited}

ARCADIS, 2003, Comprehensive groundwater model report: US NWIRP/Northrup Grumman, April 28, 2003.

ARCADIS, 2010, Comprehensive Feasibility Study Volume 2-Study Area Feasibility Study, Operable Unit 3 (former Grumman Settling Ponds): Bethpage, New York, DRAFT, November 10, 2010.

Busciolano, R.J., 2005, Statistical analysis of long-term hydrologic records for selection of drought-monitoring sites on Long Island, New York: U.S. Geological Survey Scientific Investigations Report 2004-5152, 47 p., at http://ny.water.usgs.gov/ pubs/wri/sir045152/.

Doherty, J.E., and Hunt, R.J., 2010, Approaches to highly parameterized inversion-A guide to using PEST for groundwatermodel calibration: U.S. Geological Survey Scientific Investigations Report 2010-5169, 59 p.

Festger, A., and Walter, G., 2002, The capture efficiency map: the capture zone under time-varying flow: Ground Water, v. 40(6), p. 619-628.

Flach, G.P., Crisman, S.A., and Molz, F.J. III, 2004, Comparison of single-domain and dual-domain subsurface transport models: Ground Water, v. 42 (6-7), p. 815-28.

Franke, O.L., and Cohen, Philip, 1972, Regional rates of ground-water movement on Long Island: U.S. Geological Survey Professional Paper 800-C, p. C271-C277.

Konikow, L., 2010, The secret to successful solute-transport modeling: Ground Water, v. 49(2), p. 144-159.

Misut, P.E., and Busciolano, R.J., 2009, Hydraulic properties of the Magothy and Upper Glacial aquifers at Centereach, Suffolk County, New York: U.S. Geological Survey Scientific Investigations Report 2009-5190, 23 p., at http://pubs.usgs.gov/ $\operatorname{sir} / 2009 / 5190$.

Newell, C., 2011, "Overview of Matrix Diffusion Processes and its effects on managing chlorinated solvent sites: Groundwater Resources Association of California, podcast accessed March 1, 2011, at http://grac.org/GRACast_MatrixDiffusion_Mar2011. pdf.

Occidental Chemical Corporation, 1996, Prediction of chlorinated solvent migration in the Bethpage Regional Aquifer, October 1996: ref\# 6883(11).

Olcott, P.G., 1995, Ground water atlas of the United States: U.S. Geological Survey Hydrologic Atlas HA 730-M. 
Reilly, T.E., Buxton, H.T., Franke, O.L., and Wait, R.L., 1983, Effects of sanitary sewers on ground-water levels and streams in Nassau and Suffolk Counties, New York, Part 1-Geohydrology, modeling strategy, and regional evaluation: U.S. Geological Survey Water-Resources Investigations Report 82-4045, 45 p.

Reilly, T.E., and Harbaugh, A.W., 2004, Guidelines for evaluating ground-water flow models: U.S. Geological Survey WaterResources Investigations Report 2004-5038, 28 p.

Reilly, T.E., and Pollock, D.W., 1995, Effect of seasonal and long-term changes in stress on sources of water to wells: U.S. Geological Survey Water-Supply Paper 2445, 25 p.

Reilly, T.E., and Pollock, D.W., 1996, Sources of water to wells for transient cyclic systems: Ground Water, v. 34(6), p. 979988.

Smolenksy, D.A., and Feldman, S.M., 1995, Three-dimensional advection transport of volatile organic compounds in ground water beneath an industrial/residential area of Nassau County, New York: U.S. Geological Survey Water-Resources Investigations Report 92-4148, 53 p. 


\section{Glossary of Terms and Acronyms}

Specialized technical terms are defined below. Definitions pertaining to regulation are taken from http://www.nysdec.gov and http://www.epa.gov.

A

Advection A transport mechanism of a substance by a fluid, due to the fluid's bulk motion in a particular direction.

Anisotropy the property of being directionally dependent, as opposed to isotropy which implies identical properties in all directions. An example of an anisotropic material is wood, which is easier to split along its grain than against it.

\section{B}

BWD Bethpage Water District.

C

Confining unit A layer of geologic material which impedes the movement of water into and (or) out of an aquifer.

\section{D}

Diffusion The spread of particles through random motion from regions of higher concentration to regions of lower concentration.

Dual domain porosity An aggregated porosity of media consisting of slowly and rapidly conducting pore sequences.

\section{$\mathbf{F}$}

FS Feasibility study.

G

Gardiners Clay A shallow marine or brackish-water deposit of late Pleistocene age, underlying the upper glacial aquifer on parts of the south shore of Long Island. Its northern extent varies from 3 to 5 miles inland and is indented by long, narrow northsouth channels.

\section{H}

Heterogeneity Lack of uniformity in composition or character.

Homogeneous Uniform in composition or character.

Hot spot A small area of intense or important activity embedded in a larger area of relative calm.

\section{I}

Interim remedial measure (IRM) A discrete set of activities to address both emergency and non-emergency site conditions, which can be undertaken without extensive investigation and evaluation, to prevent, mitigate, or remedy human exposure and (or) environmental damage or the consequences of human exposure and (or) environmental damage attributable to a site.

Interpolation calculation of the value of a function between the values already known.

\section{K}

Kriging A form of statistical modeling that interpolates data from a known set of sample points to a continuous surface.

\section{$\mathbf{L}$}

Least squares minimization The best fit in the least-squares; minimizes the sum of squared residuals, a residual being the difference between an observed value and the fitted value provided by a model.

Lloyd aquifer The Lloyd Aquifer is the deepest and oldest of Long Island's aquifers, composed of fine to coarse sand and gravel with a clayey matrix and some layers of silty or solid clay. Derived from stream erosion of areas to the north and west during the late Cretaceous age (60-100 million years ago). 
Magothy aquifer The largest of Long Island's aquifers, composed of river delta sediments that were deposited on top of the Raritan Formation during the late Cretaceous age (60-100 million years ago). Fine to medium sand is interbedded with clay and sandy clay of moderate permeability and silt and clay of low to very low permeability. The basal zone commonly contains coarse sand and gravel.

MODFLOW U.S. Geological Survey groundwater-flow modeling software.

MODPATH U.S. Geological Survey particle tracking analysis software.

Monitoring wells Wells (often small-diameter wells) drilled for the purposes of measuring water levels and testing water quality. Monitoring wells are not typically used to supply water.

MT3D Solute transport modeling software developed at University of Alabama.

\section{$\mathbf{N}$}

NCDH Nassau County Department of Health.

NYSDEC New York State Deparatment of Environmental Conservation

NWIRP Naval Weapons Industrial Reserve Plant.

\section{0}

ONCT Onsite containment system.

Operable Unit (OU) Addresses geographical portions of a site, specific site problems, or initial phases of an action, or may consist of any set of actions performed over time or any actions that are concurrent but located in different parts of a site.

Outpost monitoring well An early warning system.

0xy site USEPA Hooker/Ruco superfund site.

$\mathbf{P}$

Park Bethpage Community Park.

Parsimony Use of the simplest or most frugal route of explanation available.

Particle tracking analysis Water particles tracked through time assuming they are transported by advection using a simulated flow field. Particles can be tracked either forward in time or backward in time. This qualitative approach does not conserve mass.

Permeability A measure of the ability of a material (such as rocks) to transmit fluids.

PEST software package for parameter estimation and uncertainty analysis of complex environmental and other computer models.

Pilot points Interpolation points used in parameter estimation, may replace parameter zones.

Plume Body of contaminated groundwater flowing from a specific source. The movement of the groundwater is influenced by such factors as local groundwater-flow patterns, the character of the aquifer in which groundwater is contained, and the density of contaminants.

Porosity Is a measure of the void spaces in a material, and is a fraction of the volume of voids over the total volume, between $0-1$, or as a percentage between $0-100$ percent.

PPB parts per billion.

$\mathbf{R}$

Raritan confining unit Underlies the Magothy aquifer, derived from stream erosion of areas to the north and west during the late Cretaceous age (60-100 million years ago).

Record of decision (ROD) A public document that explains which cleanup alternatives will be used to clean a contaminated site.

Remedial Investigation (RI) Determines the nature and extent of contamination. Assesses the treatability of site contamination and evaluates the potential performance and cost of treatment technologies.

Residual The error in a result. 
Sensitivity analysis A technique for systematically changing parameters in a model to determine the effects of such changes.

Sorbed The physical adherence or bonding of ions and molecules onto the surface of another phase.

Steady state A system is in steady state if its behavior is unchanging.

$\mathbf{T}$

TVOC Total volatile organic compounds (VOCs).

\section{U}

Upper glacial aquifer An unconfined aquifer directly underlying the Long Island ground surface. The upper glacial aquifer was formed during the last ice age.

USEPA U.S. Environmental Protection Agency. The mission of USEPA is to protect human health and the environment.

USGS U.S. Geological Survey, a science agency that provides impartial information on the health of our ecosystems and environment, the natural hazards that threaten us, the natural resources we rely on, the impacts of climate and land-use change, and the core science systems that help us provide timely, relevant, and usable information.

V

VOC Volatile organic compound.

VPB Vertical profile borings.

W

Water table The top of an unconfined aquifer below which the pore spaces are generally saturated; the level in the saturated zone at which the pressure is equal to the atmospheric pressure. 
This page has been left blank intentionally. 
Table 1. History of Bethpage groundwater model applications and updates.

(K. Smith, Northrup Grumman, written commun., 2011 a²)

\section{Model applications and updates}

1995: Original Bethpage groundwater-

flow model developed, consisting of groundwater-flow model (MODFLOW) and particle tracking model (MODPATH)
Design onsite groundwater containment system to prevent offsite migration of contaminated groundwater from former Grumman \& NWIRP facilities.
2000: Model used to support evaluation of groundwater remedial alternatives in OU2 Feasibility Study (FS).

Model updated to add solute transport code (MT3D)

2002: Model used to support implementation of OU2 ROD.

Model updated to:

- Expand model domain laterally in all directions

- Add additional vertical model layers

- Update hydraulic conductivity zonation, natural recharge, and well pumping/ recharge rates

2003: Model used to evaluate modification of proposed GM-38 area system design

2004: Model used to evaluate modifications to ONCT system
- Evaluate groundwater alternatives in OU2 FS.

- Predict contaminant mass loadings, maximum concentrations, and cleanup time frames at remedial wells under various cleanup alternatives.

Results

- Designed and installed onsite containment system (ONCT), which became fully operational as an interim remedial measure (IRM) in 1998, and has removed over 150,000 pounds of VOCs through 2010.

- Ongoing monitoring shows ONCT has been highly effective in preventing offsite migration of contaminated groundwater.

- Validated continued use of ONCT system IRM as permanent remedy.

- 8 alternatives presented in FS for remediating onsite and offsite impacted groundwater from former Grumman \& NWRIP facilities (including GM-38 Area).

- NYSDEC OU2 ROD, issued in 2001, selected Alternative 3 from FS, consisting of continued operation of ONCT, installation of GM-38 area system, and implementation of stateapproved contingency plan for municipal wellhead treatment.

- Design remedial wells for GM-38 area.

- Design outpost wells to serve as early warning of potential VOC impacts to public-supply wells.
Evaluate functional feasibility of adding a 3rd remedial well to GM-38 area proposed 2-well system (to address Bethpage Water District input).

Evaluate if recharge from recovery wells to onsite basins could be reduced (to supply treated water to Calpine, and reduce potable water consumption) while effectively maintaining overall ONCT recovery well capture zone.
- Determined number, locations, depths, and required flow rates for remedial wells in GM-38 area to achieve maximum mass removal in this contamination "hotspot".

- Determined locations and screen depths for outpost wells to serve as early warning of potential VOC impacts to public-supply wells (S. Farmingdale Wellfields 1 and 3, Aqua, New York Wells 3S and 4S, and Town of Hempstead Well 13).

Determined that addition of 3rd remedial well offered no additional benefits for mass removal or reducing concentrations at downgradient supply wells.

- Results indicated flow to recharge basins could be reduced without compromising effectiveness of ONCT system, while saving potable water.

- Northrop Grumman provides treated water to Calpine in exchange for electric power for portion of ONCT system. 
Table 1. History of Bethpage groundwater model applications and updates.-Continued

(K. Smith, Northrup Grumman, written commun., 2011 $\mathrm{a}^{2}$ )

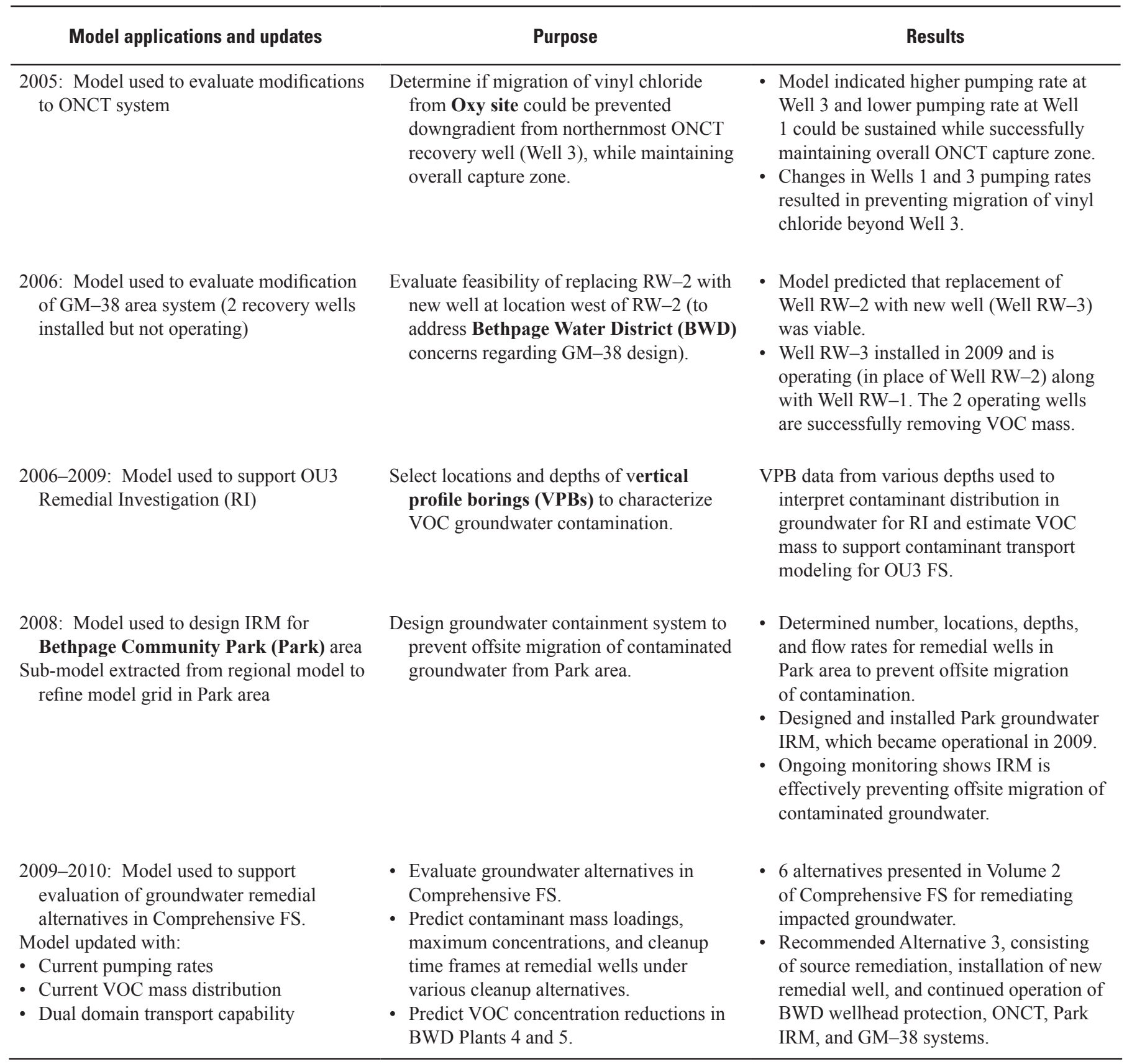


This page has been left blank intentionally. 
Prepared by the Pembroke Publishing Service Center

For additional information write to: New York Water Science Center

U.S. Geological Survey

2045 Route 112, Bldg. 4

Coram, NY 11727

Information requests:

(518) 285-5602

or visit our Web site at: http://ny.water.usgs.gov 


$$
\text { 蔰 }
$$

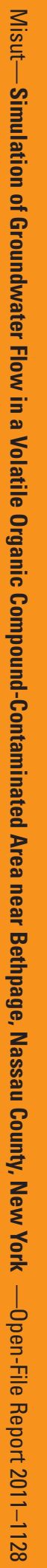

